\title{
AGRONOMIC PERFORMANCE AND CORRELATION ANALYSIS OF FINGER MILLET (Elusine corocana L.) GENOTYPES
}

\author{
Narayan Bahadur Dhami1*, Manoj Kandel1, Suk Bahadur Gurung1, Jiban Shrestha2 \\ 1Nepal Agricultural Research Council, Hill Crop Research Program (HCRP), Kabre, Dolakha \\ 2National Commercial Agriculture Research Program,Pakhribas, Dhankuta,Nepal \\ *Corresponding Author Email: nbdhami@gmail.com
}

This is an open access article distributed under the Creative Commons Attribution License, which permits unrestricted use, distribution, and reproduction in any medium, provided the original work is properly cited.

\begin{tabular}{|c|c|}
\hline ARTICLE DETAILS & ABSTRACT \\
\hline $\begin{array}{l}\text { Article History: } \\
\text { Received } 12 \text { November } 2017 \\
\text { Accepted } 12 \text { December } 2017 \\
\text { Available online 1 January } 2018\end{array}$ & $\begin{array}{l}\text { Considering the context of climate change and food security issues of the poor, marginalized and vulnerable } \\
\text { farmers; there is urgent need of characterization of the traits and its correlation in the different genotypes of } \\
\text { finger millet for development of elite variety in Nepal. A field research was carried out at agronomy field at hill } \\
\text { crop research program (HCRP), kabre, Dolakha from June to November, } 2017 \text { in order to identify the phenotypic } \\
\text { variability of the trait in different Nepalese landraces and create to promote the production and stability of } \\
\text { neglected crops, finger millet. The field experiment was conducted in random complete block design with two } \\
\text { replications. The result revealed that the finger millet genotypes showed the significant differences for days to } \\
50 \% \text { heading, plant height, plant stand per square meter, bearing head per square meter, number of finger per } \\
\text { head, thousand grain weight and grain yield. The genotypes ACC\#513 ( } 3.68 \mathrm{t} / \mathrm{ha} \text { ) fallowed by ACC\#2303( } 3.65 \mathrm{t} / \mathrm{s} \text { / } \\
\text { ha), ACC\#2275 ( } 3.57 \mathrm{t} / \mathrm{ha} \text { ) and ACC\#5434 (3.39 t/ha) produces highest grain yield. Correlation analysis } \\
\text { revealed that plant height fallowed by plant stand per square meter, bearing head, number of finger per head } \\
\text { and straw yield with minimum lodging percentage were most yield determinative traits and simultaneous } \\
\text { selection for these traits might brining an improvement in finger millet grain yield. }\end{array}$ \\
\hline
\end{tabular}

\section{KEYWORDS}

Finger millet, Characterization, Correlation, Grain yield

\section{INTRODUCTION}

Finger millet is thought to be have originated from Uganda or neighboring Ethiopian highlands where wide diversity of the genus Eleusineexists [1]. There was confliction about origin of the Eleusinecoracana either from the E. indica or from the E. Africana or from the cross of two diploid species. Nepal has diverse climate, topography and altitude which make diverse in crops. Finger millet (Elusinecorocana (L.) Gaertn.) ranks 4th in the world among mostly grown cereals after the sorghum, pearl millet and foxtail millet and 4th in Nepal in case of area of production $(2,66,799$ hectare), total production $(3,02,397 \mathrm{M}$ tons $)$ and productivity after paddy, maize and wheat [2]. It is an annual hardy cereal crop grown in the tropical, subtropical areas of world. Nepal is rich in finger millet genotypes, grown upto $3150 \mathrm{~m}$ [3]. About 790 accessions have been collected from various parts of Nepal [4]. Large diversity within Eleusinecoracana, two wild species-E. indicaand E. aegypticawas found [5]. It's productivity has depend on wide range of environments and growing conditions, from southindia to the foothills of the Himalayas in Nepal and throughout the middle-elevation areas of Eastern and Southern Africa [6,7]. Gandaki, Bagmati, Sagarmatha and Lumbini zones are major finger millet producing zones in Nepal [8]. Thus, finger millet diversity in Nepal is rich at both varietal and population levels and this diversity could be used for variety improvement [9].

Finger millet can be ground and cooked into cakes, puddings or porridge. The grain is made into fermented drink or beer in Nepal and in many parts of Africa. In central terai of Nepal, it is used as tiffin, for making haluwa, roti and chokha. It is also assumed to be a good diet for pregnant women and for treatment of animal diarrhea [10]. Finger millet protein has a favorable amino acid spectrum that includes cystine, tyrosine, tryptophan and methionine [11]. The increase global temperature leads climate change directly effects in the production of the crops and increase in hunger and malnutrition in world people, but finger millet can minimize the hunger and malnutrition because it can withstand in the drought condition and have number of macro and micro nutrients. Nutritional values of finger millet contain, moisture $13.24 \%$, protein $7.6 \%$, carbohydrate $74.36 \%$, fiber $1.52 \%$, minerals $2.35 \%$, fat $1.35 \%$, energy $341.6 \mathrm{cal} / 100 \mathrm{~g}$ [12].
Therefore, diversity in inter population and intra population in the finger millet could save the world from the scarcity of food. Mostly people are concerning to develop only handful cereals crops like maize, wheat, rice etc. in these days may cause food insecurity within few years because of increase in population of world and depletion of area of production. Development of elite variety and hybrid variety can be produced once the genetic and its phenotypic variability of character are assessed in land races. The research has main focused on the characterization of the trait and its correlation in the different traits. The research will identify the phenotypic variability of the trait in different Nepalese landraces and create to promote the production and stability of neglected crops, finger millet.

\section{MATERIALS AND METHODS}

\subsection{Research site, soil properties and Agro-meteorological condition}

The field experiment was conducted on fingermillet research field at NARC, Hill Crop Research Program (HCRP) Dolakha, Nepal, from June to November 2017. The precise location of experimental site was $27^{\circ} 39^{\prime}$ $59.99^{\prime \prime} \mathrm{N}$ latitude, $86^{\circ} 01^{\prime} 60.00^{\prime \prime} \mathrm{E}$ longitudes and at an altitude of 1700 meters above mean sea level. The soil of the experimental plot was acidic sandy to silty loam with pH 4.5 to 6.2 and poor in organic carbon and total $\mathrm{N}$ content but medium in soil available P2O5 and K20.The field were upland from where the water drained easily during rainfall because the finger millet needs the dry but slight moisture condition in soil. The climate of research location is temperate. The maximum temperature recorded was $26.60 \mathrm{C}$ in the month of September while the minimum temperature recorded was $8.60 \mathrm{C}$ during November. Average rainfall of region is $200-400 \mathrm{~mm}$ per annum and relative humidity ranges from 20 $60 \%$. During the experiment period, the field received total $1445 \mathrm{~mm}$ of rainfall with maximum rainfall of $2.9 \mathrm{~mm}$ in November. The meteorological data were obtained from meteorological station, HCRP Dolakha.

2.2 Plant materials, raising of seedlings, field layout and transplanting

The plant materials tested in the research were 16 elite finger millet genotypes for development of climate resilience high yielding biotic and 
abiotic stress tolerance genotypes suitable for hill growing condition for sole cropping system. Dry nursery beds were established for each genotype on 1th July 2017. Each nursery row was $1 \mathrm{~m}$ in length and supplied with equal amount of farmyard manure. No chemical fertilizers were applied on nursery beds. The seed rate applied was $8 \mathrm{~kg}$ ha-1. The age of seedlings was 27 days during transplanting. The field experiment was conducted in Random complete block design (RCBD). The trial was replicated twice. Each replication comprised sixteen blocks/plots. Randomization of experimental material will be done with the software CROPSTAT. Each plot contains same levels of fertilizers i.e - $50: 30: 00$ NPK kg ha-1. Half dose of urea and full dose of DAP and applied as basal while remaining half dose of urea was top dressed in split at 30 DAT. Each plot was $2 \mathrm{~m}$ in length and $2 \mathrm{~m}$ in width. Transplanting of 2-3 seedlings per hill was done on 28th November with a spacing of $10 \mathrm{~cm}$ between rows and $10 \mathrm{~cm}$ between hills in each plot. There was a gap of $0.5 \mathrm{~m}$ between plots and $2 \mathrm{~m}$ between within a replication. There was 2.0 $\mathrm{m}$ gap between the replication. Bunds were constructed in between plots and replications. Weeds are the major problem in finger millet, especially during 2-3 weeks after sowing. Therefore, weeding or hoeing was done at every 15 days after the 25 days of sowing. And other management practices were done as like those for recommended varieties. Plants was protected against any source of variations other than those included in the treatments. There is no irrigation is required but left to receive natural precipitation. The list of genotypes of finger millet included in the study is presented in Table 1.

Table 1: Names genotypes of finger millets used for research at HCRP (2017)

\begin{tabular}{|llllll|}
\hline S. N & Name of genotypes & S.N. & Name of genotypes & S.N. & Name of genotypes \\
\hline 1 & ACC\#2275 & 7 & ACC\#512 & 13 & ACC\#6542 \\
2 & ACC\#2286-1 & 8 & ACC\#2844 & 14 & GE-0012 \\
3 & ACC\#2301 & 9 & ACC\#513 & 15 & GE-0480 \\
4 & ACC\#2303 & 10 & ACC\#5434 & 16 & Kabre Kodo-1 \\
5 & ACC\#2400 & 11 & ACC\#6308 & & \\
6 & Local Variety & 12 & ACC\#6369 & & \\
\hline
\end{tabular}

\subsection{Data collection}

Observation will be taken for the following parameters as such as DTH $(50 \%)=$ Days to $50 \%$ heading, $\mathrm{PH}=$ plant height $(\mathrm{cm}), \mathrm{PS}=$ Plant stand per square meter, $\mathrm{BH}=$ Baring heads per square meter, $\mathrm{NF} / \mathrm{H}=$ Number of finger per head, LS\%= lodging percentage, TGW= thousand grain weight (gram), GY = grain yield ( $\mathrm{t} / \mathrm{ha}$ ) and $\mathrm{SY}=$ straw yield $(\mathrm{t} / \mathrm{ha})$ per the descriptors for finger millet [13]. Data on days to $50 \%$ heading, plant stand and baring head and straw yield were recorded on plot basis. Whereas, plant height $(\mathrm{cm})$ and number of finger per head was recorded on five selected representative plants. Thousand kernel weights were measured by counting 1000 grains from the bulk of each plot after shelling and weighed in grams after the moisture was adjusted to $15 \%$. Lodging percentage was measured in scale 1 to 5 . Lodging should be recorded on the scale of 1 to 5 indicating $1=0-20 \%, 2=20-40 \%, 3=40$ $60 \%, 4=60-80 \%$ and $5=80-100 \%$. Grain yield per plot adjusted to 12 $\%$ grain moisture and converted to kilogram per hectare on basis by using following formula.

Grain yield $(\mathrm{kg} / \mathrm{ha})=\underline{\text { GYPP } \times 10000 \times(100-\mathrm{GMC})}$

$\mathrm{NHA} \times 88$

Where, GYPP = Grain Yield per plot $(\mathrm{kg}), \mathrm{GMC}=$ grain moisture content at harvest $(\%), \mathrm{NHA}=$ Net harvested area $\left(\mathrm{m}^{2}\right)$.

\section{STATISTICAL ANALYSIS}

The data recorded on different parameters from field were first tabulated and processing in Microsoft excel (MS- Excel, 2010), then subjected GenStat to obtain ANOVA and all values were expressed as mean values. Correlation coefficients of different traits using SPSS program were carried out using the formula given by researchers through a study [14]. $P$ values less than 0.05 and 0.01 were considered statistically significant and statistically highly significant, respectively.

\section{RESULTS AND DISCUSSION}

The present study genetic diversity among 16 finger millet genotypes was analyzed on the basis of eight agro morphological traits. The result of descriptive analysis (Table 2) showed that lodging had highest variation (32.9) fallowed by straw yield (31.9\%), grain yield (20.4) and number of finger per head (11.1). Among traits days to $50 \%$ heading showed the lowest (2.2) fallowed by thousand grain weight (4.8), plant height (8.1). Significant variation among finger millet genotypes for grain yield, thousand grain weight, number of finger per head, baring head per square meter, plant stand per square meter, plant height, days to $50 \%$ heading and lodging percentage. The mean value of observed traits day to $50 \%$ heading (65), plant height $(86 \mathrm{~cm})$, plant stand per meter square (87) Baring Head (132), number of finger per head (6) thousand grain weight (1.13), grain yield $(2.85 \mathrm{t} / \mathrm{ha})$ and straw yield $(8.38 \mathrm{t} / \mathrm{ha})$ as presented in Table 2.The genotypes ACC\#513 (3.68 t/ha) fallowed by ACC\#2303 (3.65t/ha), ACC\#2275 (3.57t/ha) and ACC\#5434 (3.39) produces maximum yield whereas genotypes ACC\#6308 (1.5 t/ha) and GE-002 (1.6 t/ha) produces minimum yield under study condition.

Table 2: Descriptive statistics of agro morphological traits of 16 finger millet genotypes at HCRP, Kabre, Dolakha (2018)

\begin{tabular}{|c|c|c|c|c|c|c|c|c|c|}
\hline Name of genotypes & $\begin{array}{r}\text { DTH } \\
(50 \%)\end{array}$ & $\begin{array}{l}\mathrm{PH} \\
(\mathrm{cm})\end{array}$ & PS & $\mathrm{BH}$ & $\mathrm{NF} / \mathrm{H}$ & lodging\% & TGW & GY(t/ha) & $S Y(t / h a)$ \\
\hline ACC\#2275 & 67.5 & 83.5 & 66.5 & 163.5 & 6.5 & 1 & 0.875 & 3.57 & 8.55 \\
\hline ACC\#2286-1 & 72.5 & 84.9 & 71 & 110 & 6.2 & 1.5 & 1.04 & 2.38 & 6.86 \\
\hline ACC\#2301 & 64 & 91 & 89 & 150.5 & 6.4 & 1 & 1.01 & 2.83 & 8.81 \\
\hline ACC\#2303 & 63 & 90.9 & 89 & 118 & 5.5 & 1 & 1.31 & 3.66 & 10.74 \\
\hline ACC $\# 2400$ & 66 & 83.5 & 74.5 & 130 & 5.3 & 1 & 1.14 & 2.93 & 8.27 \\
\hline ACC\#512 & 64 & 91.7 & 79.5 & 130 & 5.8 & 1 & 1.16 & 3.14 & 9.22 \\
\hline ACC\#2844 & 67.5 & 88.5 & 85.5 & 127 & 5 & 1 & 1.25 & 3.31 & 8.95 \\
\hline ACC\#513 & 64.5 & 87.8 & 87 & 181.5 & 5.4 & 1 & 1.16 & 3.68 & 11.34 \\
\hline ACC\#5434 & 65 & 95.1 & 61.5 & 113 & 4.8 & 1 & 1.305 & 3.39 & 10.22 \\
\hline ACC\#6308 & 63 & 65 & 68.5 & 139.5 & 6 & 3 & 1.05 & 1.5 & 3.41 \\
\hline ACC\#6369 & 72.5 & 79.7 & 75.5 & 122 & 6.6 & 1.5 & 0.975 & 2.2 & 6.24 \\
\hline ACC\#6542 & 67.5 & 84.5 & 63.5 & 107.5 & 4.95 & 1 & 1.335 & 2.94 & 8.69 \\
\hline GE-0012 & 62 & 75.5 & 69 & 133 & 6.4 & 3 & 0.985 & 1.68 & 5.7 \\
\hline GE-0480 & 63 & 82.9 & 75 & 147.5 & 5.4 & 2.5 & 0.97 & 2.48 & 5.81 \\
\hline Kabre Kodo-1 & 64.5 & 90.9 & 82 & 123.5 & 4.6 & 1 & 1.2 & 2.48 & 12.55 \\
\hline Local variety & 63.5 & 100.5 & 72.5 & 121 & 4.8 & 1 & 1.38 & 2.7 & 8.75 \\
\hline Grand Mean & 65.62 & 86 & 87 & 132.3 & 5.6 & 1.406 & 1.1325 & 2.85 & 8.38 \\
\hline $\mathrm{F}$-test & $<.001$ & 0.028 & 0.206 & 0.006 & 0.053 & 0.002 & $<.001$ & 0.037 & 0.211 \\
\hline C.V.(\%) & 2.2 & 8.1 & 13.2 & 10.8 & 11.1 & 32.9 & 4.8 & 20.4 & 31.9 \\
\hline $\operatorname{LSD}(0.05)$ & 1.09 & 5.3 & 7.52 & 10.7 & 0.48 & 0.35 & 0.06 & 0.44 & 2.02 \\
\hline
\end{tabular}

$*$ and ${ }^{* *}$, significant at $5 \%$ and $1 \%$ probability level. DTH (50\%)= Days to $50 \%$ heading, $\mathrm{PH}=$ Plant height $(\mathrm{cm}), \mathrm{PS}=$ Plant stand square meter -1 , $\mathrm{BH}=$ Bearing head square meter-1,NF/H= Number of finger head-1, TGW= Thousand grain weight, GY= Grain yield $(\mathrm{t} / \mathrm{ha})$ and $\mathrm{SY}=$ Straw yield $(\mathrm{t} / \mathrm{ha})$.

\subsection{Correlation analysis}

Analysis of variance exhibited significant difference among genotypes for different traits. The grain yield had positive significant correlation with plant height fallowed by plant stand per square meter, baring head per square meter, number of finger per head and straw yield and significant negative correlation with lodging percentage. The plant height was found significant positive association with straw yield fallowed by thousand kernel weight where as significant negative association with number finger per head. Thousand grain weight were found significant negative correlation baring head per square meter and number finger per head. Significant positive association between lodging percentage and straw yield and significant negative association between plant height and thousand kernel weight.

Table 3: Pearson's Correlation coefficient among different traits of finger millet under at HCRP, Dolakha (2018).

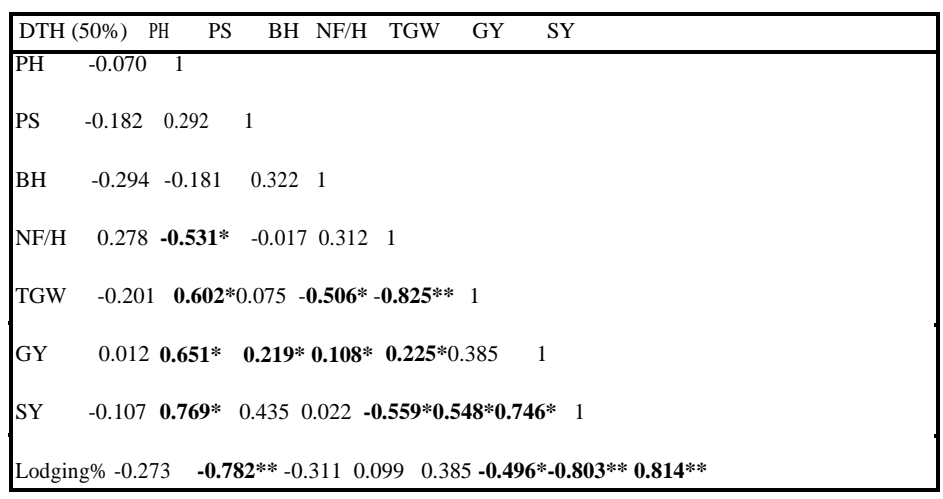

Values are significant difference at $5 \%$ level of significance $(*)$ and highly significant at $1 \%$ level of significant $(* *)$, DTH $(50 \%)=$ Days to $50 \%$ heading, $\mathrm{PH}=$ Plant height $(\mathrm{cm}), \mathrm{PS}=$ Plant stand per square meter, $\mathrm{BH}=$ Bearing head per square meter, $\mathrm{NF} / \mathrm{H}=$ Number of finger per head, $\mathrm{TGW}=$ Thousand grain weight, $\mathrm{GY}=$ Grain yield $(\mathrm{t} / \mathrm{ha})$ and $\mathrm{SY}=\mathrm{Straw}$ yield $(\mathrm{t} / \mathrm{ha})$.

In present study there is sustainable genetic variability in different morphphysiological and yield attributing traits of finger millet genotypes. A researcher reported that significance amount of variability in finger millet genotypes for different morph- physiological and yield attributing traits in three environmental conditions over three years [15]. The genotypic variability among finger millet genotypes was not influenced by 
environmental condition in characters such as days to heading, finger width, finger length, and days to maturity, culm thickness and grain yield per plant similar result was reported [16]. A group researcher also found variation in the morphological characters such as $63.5 \%$ were green plant type accessions from 909 accessions: $92.8 \%$ types are erect in growth habits: varies in mean plant height, mean time to $50 \%$ flowering, mean inflorescence length and width, mean of panicle exertion ranges from 90 $104 \mathrm{~cm}, 65-81$ days, $88-104 \mathrm{~mm}, 55-103 \mathrm{~mm}$ and $75-110 \mathrm{~mm}$ respectively that showed exist of diversity and which directly affects in yield of finger millet [17]. In a study, reported similar result of variability at intra population level in all quantitative traits and similarly, higher polymorphism observed in 11 qualitative characters (ear shape followed by grain number) and plant stand, finger length, number of finger per head, baring head, finger width and grain yield were distributed in significant skewness [18]. In other study also the researchers observed that grain yield was positively correlated with, finger width baring head, and number of finger per head and he also notified that variation in these traits cause diversity in Intra- and inter population of finger millet [18]. Some researchers also reported that grain yield was positively correlated with plant height [19]. The similar result of positive correlation between plant height number of finger per head with grain yield also reported in a study [20]. In variability analysis among 400 finger millet germplasms was found positive association between grain yield with productive tillers, fingers per ear and finger length and plant height [21]. In other study also, researcher reported similar result as grain yield was positive number of finger per head and baring head [18]. Others, there a researchers also reported that the correlation of grain yield with straw yield and harvest index at genotypic and phenotypic level [22].

\section{CONCLUSION}

The genetic diversity was observed in different genotypes of finger millet for traits such as grain yield fallowed by days to $50 \%$ heading, plant height, plant stand per square meter, bearing head per square meter, number of finger per head, and thousand grain weight under study condition. Plant height fallowed by plant stand per square meter, bearing head, number of finger per head and straw yield with minimum lodging percentage were most yield determinative traits as revealed from correlation analysis and hence simultaneous selection for these traits might brining an improvement in finger millet grain yield under condition. Thus, presence of high level of diversity among the genotypes of finger millet for grain yield indicated their superior trait value for study condition; these genotypes may be of interest to researcher for further breeding purpose.

\section{ACKNOWLEDGEMENTS}

The author would be highly indebted to Damali Sherpa and Dinesh Kumar Nepali technical assistance (T-4) atHill Crop Research Program (HCRP) for providing valuable support during data taken in research. He would also like to thank to Hill Crop Research Program (HCRP),Dolakha for the provision of reseach materials and field.

\section{REFERENCES}

[1] Werth, C.R., Hilu, K.W., Langner, C.A. 1994. Isozymes of Eleusine (Gramineae) and the origin of finger millet. American Journal of Botany, 81, 1186-1197.

[2] MoAD. 2016. Statistical Information on Nepalese Agriculture, 2016/17 (2072/2073). Agri business promotion and statistical division, Agristatistic section, Singhdurbar, Kathmandu,Nepal.

[3] Upreti, R.P. 1999. Status of millet genetic resources in Nepal: Wild relatives of cultivated plants in Nepal. In: R. Shrestha and B. Shrestha, (eds.). Wild relatives of cultivated plants in Nepal. Proceedings of National conference on wild relatives of cultivated plants in Nepal Kathmandu. Green Energy Mission (GEM), Kathmandu, 2 (4), 78-82.

[4] Upadhyay, M.P., Joshi, B.K. 2003. Plant genetic resources in SAARC countries: Their conservation and management. Nepal chapter. SAARC Agriculture Information Center, 297-422.

[5] Hunsigi, G., Krishna, K.R. 1998. Science of field crop production; Finger millet. New Delhi Oxford and IBH publishing Co pvt.ltd.132

[6] ICRISAT. 2004. Finger millet. http://www.icrisat.org/web/ASP/ mainsection.asp (Retrieved on 15 June, 2011).

[7] Adhikari, R.K. 2005. Economics of underutilized crop: A case of finger millet from Peri urban area of Pokhara valley, Thesis, M.Sc. Ag., Tribhuvan University, IAAS, Rampur, Chitwan, Nepal.
[8] Baniya, B.K., Riley, K.W., Dongol, D.M.S., Sherchand, K.K. 1992. Characterization of Nepalese hill crops landraces (Barley, Buckwheat, Finger millet, Grain Amaranth, Foxtail, Proso and Barnyard millets), NARC-IBPGR, Kabre, Dolakha, Nepal.

[9] Rana, R.B., Rijal, D.K., Gauchan, D., Sthapit, B.R., Subedi, A., Upadhyay, M.P., Pandey, Y.R., Jarvis, D.I. 2000c. In situ crop conservation: Findings of agro-ecological, crop diversity and socio-economic baseline survey of Begnasecosite, 2. Kaski, Nepal. NARC, LI-BIRD and IPGRI.

[10] Rachine, K.O. 1975. The Millets: Importance, Utilization and Outlook. International Crops Research Institute for the Semi-Arid Tropics, Hyderabad, India, 63.

[11] Vadivoo, A.S., Joseph, R. 1998. Genetic variability and diversity for protein and calcium contents in fingermillet (Elusinecoracona (L.) Gaertn) in relation to grain color. Plant Foods for Human Nutrition Dordrecht. Department of Botany, Avinashilingam Institute for Home Science and Higher Education for Women, Deemed University, Coimbatore, TN, 641 043, India, 52 (4), 353-364.

[12] IBPGR. 1985. Descriptors for finger millet (Elusine coracana (L.) Gaertn). Rome, Italy: International Board for Plant Genetic Resources.20. http://www2.bioversityinternational.org/publications/ Web_version/417 (Retrieved on 20 Feb, 2018).

[13] Steel, R.G.D., Torrie, J.H. 1980. Principles and procedures of statistics, a biochemical approach. McGraw Hill, Inc. New York.

[14] Mishra, R.C., Das, S., Patnaik, M.C. 2009. AMMI Model Analysis of Stability and Adaptability of Late Duration Finger Millet (Eleusine coracana) Genotypes. World Applied Sciences Journal, 6 (12), 1650-1654.

[15] Bezaweletaw, K., Sripichit, P., Wongyai, W., Hongtrakul, V. 2006. Genetic variation, heritability and path-analysis in Ethiopian finger millet (Eleusine coracana(L.) Gaertn) landraces. Kasetsart Journal, Natural Sciences, 40, 322-334.

[16] Upadhyaya, H.D., Gowda, C.L.L., Reddy, V.G. 2007. Morphological diversity in finger millet germplasm introduced from Southern and Eastern Africa. Journal of SAT Agriculture Research, 3 (1), 78-82.

[17] Amgain, R.B., Joshi, B.K., Shrestha, P., Chaudahry, B., Adhikari, N.P., Baniya, B.K. 2004. In: B.R. Sthapit, B.R., M.P. Upadhyay, P.K. Shrestha and D.I. Jarvis (eds.). Intra- and interpopulation variation in finger millet ( Eleusine coracana (L.) Gaertn) landraces grown in Kachorwa, Bara.Conference paper: On-farm conservation of agricultural biodiversity in Nepal. Volume 1: assessing the amount and distribution of genetic diversity on-farm. Proceedings of the second national workshop August 25-27, 84-95. Nagarkot,Nepal. http:// www.bioversityinternational.org/Publication/Pdf/1083.pdf Retrieved on $20 \mathrm{Feb}, 2018$.

[18] Dhagat, N.K., Pathak, G.L., Srivastava, P.S., Joshi, R.C. 1972. Correlation and genetic variability in ragi (Eleusinecoracana G.). Jawaharlal Nehru KrishiVishwa Vidyalay Research Journal, 6, 121- 124.

[19] Harinarayana, C., Shewall, T.T., Gaikwad, A.C., Haeper, P.N. 1989. Variability for components of yield in Maharashtra, Sikkim and Malawi collections of finger millet. In: Finger millet Genetics and Breeding in India. Proceedings of National Seminar, University of Agricultural Sciences, Bangalore, 119- 123.

[20] K.1996. Evaluation of finger millet germplasm. Germplasm Catalogue 1. Small Millets Project Co-ordination Unit, UAS-KAR, Bangalore,33-35.

[21] Ramakrishna, M.B., Gowda, B.T.S., Katti, M., Seetharam, A., Mantur, S.G., Viswanath, S., Channamma, K.A.L., Krishnappa, M., Vasanth, K.R., Krishnamurthi, Jagadeeswara, B. 1996. Evaluation of finger millet germplasms, Germplasm Catalogue 1. Small. Millets Project Co-ordination Unit, UAS-KAR, Bangalore, 33-35.

[22] Cauvery, M.B. 1993. Variability for fodder yield, it's components and grain yield in Indian and African collection of finger millet. M. Sc. (Agri.) Thesis, University of Agricultural Sciences, Bangalore, India.

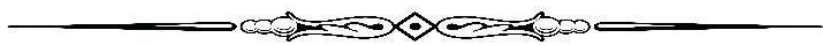

